\title{
Soluble immune checkpoints in cancer: production, function and biological significance
}

\author{
Daqian $\mathrm{Gu}^{1,2+}$, Xiang $\mathrm{Ao}^{1,2+}$, Yu Yang ${ }^{1,2}$, Zhuo Chen ${ }^{1,2}$ and Xiang $\mathrm{Xu}^{1,2^{*}}$ (D)
}

\begin{abstract}
Immune checkpoints play important roles in immune regulation, and blocking immune checkpoints on the cell membrane is a promising strategy in the treatment of cancer. Based on this, monoclonal antibodies are having much rapid development, such as those against CTLA-4 (cytotoxic T lymphocyte antigen 4) and PD-1 (programmed cell death protein 1).But the cost of preparation of monoclonal antibodies is too high and the therapeutic effect is still under restrictions. Recently, a series of soluble immune checkpoints have been found such as SCTLA-4 (soluble CTLA-4) and SPD-1 (soluble PD-1). They are functional parts of membrane immune checkpoints produced in different ways and can be secreted by immune cells. Moreover, these soluble checkpoints can diffuse in the serum. Much evidence has demonstrated that these soluble checkpoints are involved in positive or negative immune regulation and that changes in their plasma levels affect the development, prognosis and treatment of cancer. Since they are endogenous molecules, they will not induce immunological rejection in human beings, which might make up for the deficiencies of monoclonal antibodies and enhance the utility value of these molecules. Therefore, there is an increasing need for investigating novel soluble checkpoints and their functions, and it is promising to develop relevant therapies in the future. In this review, we describe the production mechanisms and functions of various soluble immune checkpoint receptors and ligands and discuss their biological significance in regard to biomarkers, potential candidate drugs, therapeutic targets, and other topics.
\end{abstract}

Keywords: Immune checkpoints, T cells, Soluble receptors and ligands, Immunotherapy, Cancer

\section{Introduction}

Immune checkpoints are molecules that can increase or decrease the signals of the immune system, and they are considered to be critical factors in treating infections, cancers and autoimmune diseases. Currently, immune checkpoint therapy is seen as a pillar of cancer therapy [1]. Among the different checkpoint therapies, those involving PD-1 and CTLA-4 may be the most effective. CTLA-4 is considered to be the first functional immune checkpoint, as it stops $\mathrm{T}$ cells in lymph nodes at the

\footnotetext{
* Correspondence: xiangxu@tmmu.edu.cn

${ }^{\dagger}$ Daqian Gu and Xiang Ao contributed equally to this work.

'Department of Stem Cell \& Regenerative Medicine, State Key Laboratory of Trauma, Burn and Combined Injury, Daping Hospital and Research Institute of Surgery, Third Military Medical University, Chongqing 400042, People's Republic of China

${ }^{2}$ First Department, State Key Laboratory of Trauma, Burn and Combined Injury, Daping Hospital and Research Institute of Surgery, Third Military Medical University, Chongqing, People's Republic of China
}

initial stage of naive T-cell activation, while the PD-1 pathway suppresses activated $\mathrm{T}$ cells at the later stages of an immune response, typically in peripheral tissues [2]. In clinical trials, the anti-CTLA-4 antibody and the anti-PD-1 antibody have shown tremendous promise against a wide spectrum of solid and hematological malignancies, significantly improving OS (overall survival) in newly diagnosed and heavily pretreated patients alike [3]. However, the influences of soluble receptors and ligands on immune regulation and cancer treatment have been less well studied. Soluble receptors and ligands, which are part of a family including full-length receptors and ligands, are produced by mRNA expression or by the cleavage of membrane-bound proteins and are found free in the plasma. These entities may play important roles in immune regulation via interactions between soluble receptors and full-length ligands or between soluble ligands and full-length receptors. For

(c) The Author(s). 2018 Open Access This article is distributed under the terms of the Creative Commons Attribution 4.0 International License (http://creativecommons.org/licenses/by/4.0/), which permits unrestricted use, distribution, and 
example, alternative splice variants of the human PD-1 and CTLA-4 genes have been identified, and SPD-1 can interfere with PD-L1/2 (programmed cell death ligand-1/ 2, also known as B7-H1/2):full-length PD-1 interactions, thereby blocking the negative signal imparted by the transmembrane form of PD-1 $[4,5]$. Several studies have documented many types of soluble receptors and ligands that can be detected in the plasma in cancer, and the plasma levels are related to the severity of cancer.

Since previous studies suggested that soluble receptors and ligands should be considered therapeutic targets in cancer, we introduce some common therapeutic targets. We also review the production of these soluble receptors and ligands and discuss related clinical findings. We not only consider the significance of these receptors and ligands with regards to the prognosis and treatment in cancer but also consider their mechanisms of action. Finally, we conclude the use of immunotherapy based on these soluble molecules.

\section{State of immune checkpoints}

Immune checkpoints can stimulate or inhibit signals in immune cells and regulate their functions; thus, the checkpoints play important roles in the maintenance of immune homeostasis [6]. For example, $\mathrm{T}$ cells need two signals for activation: binding of the TCR (T-cell receptor) and the MHC (major histocompatibility complex) and an interaction between costimulatory molecules [7]. On the contrast, PD-L1 expressed by some tumors works as a coinhibitory ligand with PD-1 to prevent T-cell activity [8].

\section{Categories of immune checkpoints}

In the immune system, checkpoints can be divided into two groups: stimulatory molecules such as TCR/MHC and inhibitory molecules such as CTLA-4/CD80 or CD86 and PD-1/PD-L1. Increasing numbers of novel receptors and ligands have recently been found in the immune system. Some take part in costimulatory interactions, such as CD137L/CD137 and OX40L/CD40 [9], while others, such as HVEM/BTLA and MHCII/LAG3 [10], are involved in inhibitory interactions. Apart from these, other receptors have also become renowned for their unique functions. For example, GAL-9/TIM-3 can induce the inhibition of Th1 cell responses [11]. In Fig. 1, we summarize the various ligand-receptor interactions

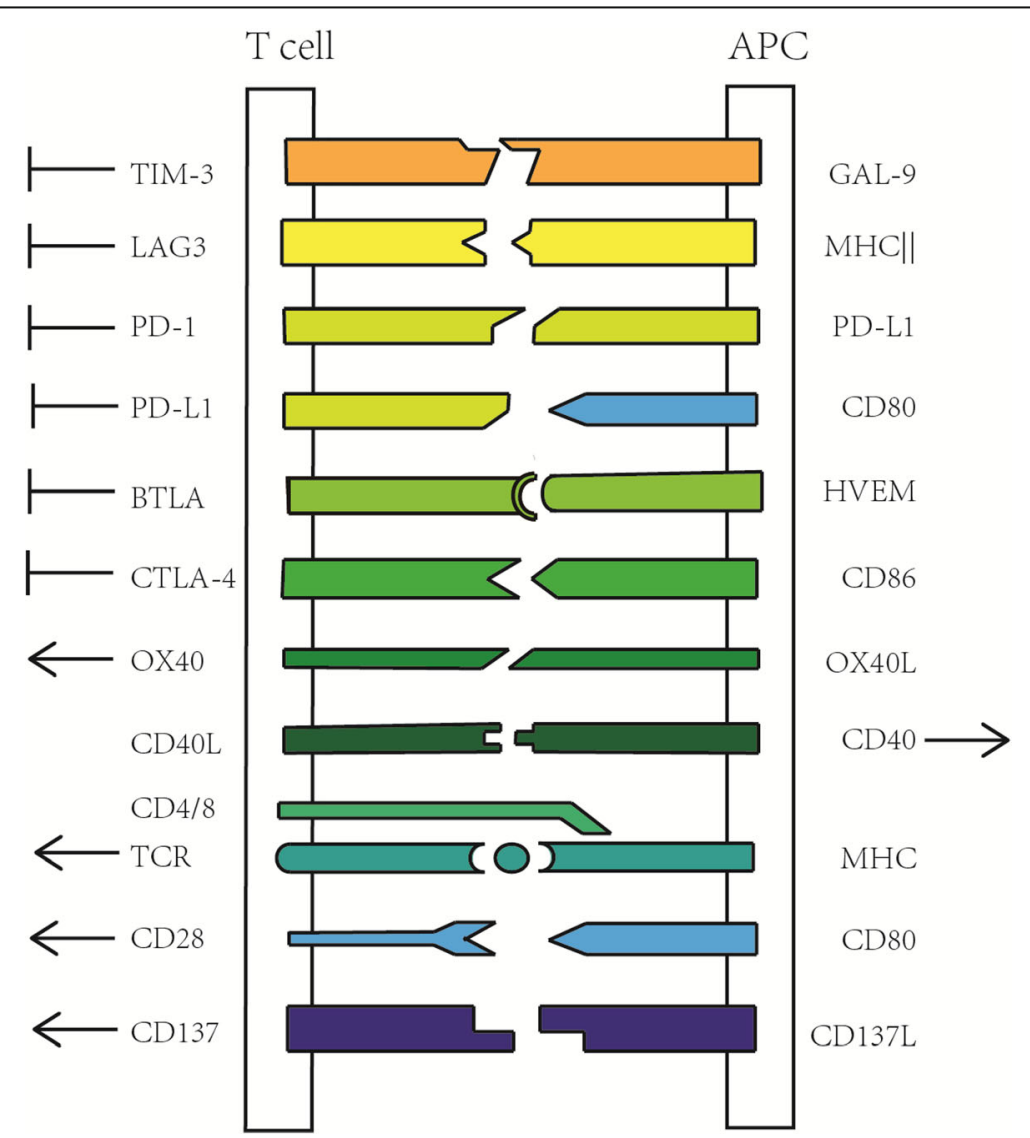

Fig. 1 Various ligand-receptor interactions between T cells and APCs (generalized to include all karyocytes). TIM-3, LAG3, PD-1, PD-L1, BTLA, and CTLA-4 are coinhibitory molecules present on the surface of T cells. OX40, TCR, CD28, and CD137 can transfer stimulatory signals into T cells, and CD40 can receive stimulatory signals from CD40L on T cells 
of immune checkpoints between T cells and APCs (antigen-presenting cells).

\section{Basic functions}

Immune checkpoints can transfer signals between different immune cells, changing their activities and regulating the secretion of cytokines in response to the microenvironment. For example, when the TCR on Th1 cells combines with MHCII on APCs, the Th1 cells are activated and can secrete IL- 2 and IFN- $\gamma$ (interferon- $\gamma$ ) to enhance the antitumor effects [12] .

PD-1 and CTLA-4 are excellent examples of immune checkpoints. Unlike other members of the CD28 family, PD-1 can only transduce signals when crosslinked with BCR or TCR. Various studies have confirmed that PD-L1 and PD-L2 are expressed in cancer cells, T cells, macrophages (mostly M2 macrophages), myeloid DCs (dendritic cells), myeloid suppressor cells, stromal fibroblasts, and endothelial cells, suggesting that PD-1/ PD-L1/PD-L2 can influence many cell types. The PD-1/ PD-L1 pathway in the TME (tumor microenvironment) can inhibit the activation of effector T cells and promote the generation of Treg cells; this shows that PD-1-induced immune suppression may cause cancer cells to escape immune surveillance [13]. The blockade of this pathway in many therapeutic strategies can promote antitumor effects. CTLA-4 is expressed in T cells, B cells, NK cells, NKT cells, and DCs. CTLA-4 is homologous to $\mathrm{CD} 28$, but it has an approximately 100-fold higher affinity for both CD80 and CD86 than CD28. Similar to PD-1, CTLA-4 inhibits T cell activation by binding to its ligand [14]. Moreover, CTLA-4 also inhibits IL-2 production and influences naive $\mathrm{CD} 4^{+} \mathrm{T}$ cell differentiation. Both antibody blockade of CTLA-4 and genetic deletion of CTLA-4 induce the generation of Th17 cells and improve Th2 cell differentiation. In addition, CTLA-4 can control not only $\mathrm{T}$ cell effector functions but also $\mathrm{B}$ cell responses by regulating the functions of $\mathrm{T}$ follicular helper cells and $\mathrm{T}$ follicular regulatory cells [15]. Though the critical role of CTLA-4 in controlling $\mathrm{T}$ cell activation and tolerance is well known, how CTLA-4 exerts its inhibitory effects remains unclear.

\section{Increased significance}

With the development of immunotherapy for cancer and other diseases, the demand for identifying immune checkpoints is growing. The FDA has approved a series of antibodies targeting these checkpoints. In addition, some novel strategies based on the principle of immune checkpoints have been developed. For example, a combination of synergistic immune checkpoint blockade and targeted therapy is used to treat metastatic melanoma [16]. Because of the need for the endogenous molecule used for therapy, the formation mechanisms and functions of soluble receptors and ligands produced by human body, such as sPD-1, are being explored [17].Due to the rapid development of Immune checkpoint therapy, it will likely become the most effective way to fight cancer, although this therapy still has some limitations, such as a lack of power in the TME [18].

\section{Soluble immune checkpoints}

In addition to the receptors and ligands of immune checkpoints on cell membrane, a series of soluble immune checkpoints have also been analyzed, and their plasma levels have been measured. These checkpoints play an important role in immune regulation, are involved in the development and prognosis of cancer, and are considered to be potential biomarkers and therapeutic targets. A summary of the information gathered on the soluble immune checkpoints is shown in Table 1.

\section{SPD-1}

\section{Production}

The sPD-1 was reported to be a monomeric protein [19]. Christian Nielsen et al. found that sPD-1 is generated from mRNA expression. Four alternatively spliced PD-1 mRNA transcripts-PD-1 $\triangle \mathrm{ex} 2, \quad \mathrm{PD}-1 \Delta \mathrm{ex} 3$, PD- $1 \triangle$ ex 2,3 , and PD-1 $\triangle$ ex $2,3,4$-were described apart from the full-length PD-1. These variants are generated by splicing out exon 2; exon 3; exons 2 and 3; and exons 2,3 , and 4 , respectively. In contrast to the other transcripts, which do not have obvious biological functions, $\mathrm{PD}-1{ }^{\triangle} \mathrm{ex} 3$ is the soluble isoform of PD-1 and increases following the activation of PBMCs [4].

\section{Prognosis}

One study on sPD-1 found that its existence in tumor tissue promotes tumor-specific immunity, and in immunocompetent mice, a striking degree of immune cell infiltration was observed on local tumor, that was thought to be related to prolonged survival [20]. In addition, in a study on NSCLC (non-small cell lung cancer), elevated sPD-1 was found in $34 \%$ of patients receiving erlotinib and these patients experienced prolonged progression-free and OS [21]. Notably, in a cohort of $2903 \mathrm{HBV}$ patients, higher sPD-1 level appears to be associated with an increased risk of HCC (hepatocellular carcinoma) [22].

\section{Biological mechanism}

SPD-1 can inhibit all three PD-L/PD-1 interactions: PD-L1/CD80, PD-L1/PD-1, and PDL2/PD-1 [23]. Osama et al. found that expressed sPD-1 blocks PD-L1/PD-1 interactions, which explains the inhibition of tumor growth after local gene transfer of sPD-1 in tumor inoculation sites [20]. Researchers have also used 
Table 1 Basic information about the soluble receptors and ligands

\begin{tabular}{|c|c|c|c|c|c|c|}
\hline $\begin{array}{l}\text { Soluble } \\
\text { receptors/ligands }\end{array}$ & Structure & Cell source & Production & Ligands/receptors & Main functions & references \\
\hline SPD-1 & Monomer & $\begin{array}{l}\text { PBMCs (peripheral blood } \\
\text { mononuclear cells) }\end{array}$ & mRNA expression & PD-L1/2 & $\begin{array}{l}\text { 1. Block PD-L/PD-1 } \\
\text { interactions } \\
\text { 2. Activate } \mathrm{CD}^{+}{ }^{-} \\
\mathrm{T} \text { cells }\end{array}$ & {$[4,19,20,23,24]$} \\
\hline sPD-L1 & Unknown & Mature DCs & $\begin{array}{l}\text { Possible cleavage } \\
\text { of membrane-bound } \\
\text { proteins }\end{array}$ & PD-1 & $\begin{array}{l}\text { 1. Combine } \\
\text { with PD-1 } \\
\text { 2. Inhibit T-cell } \\
\text { responses }\end{array}$ & {$[31,32,44]$} \\
\hline sPD-L2 & Unknown & Activated leukocytes & mRNA expression & PD-1 & Unknown & {$[45]$} \\
\hline sCTLA-4 & Monomer & $\begin{array}{l}\text { Monocytes/immature } \\
\text { DCs/Treg cells }\end{array}$ & mRNA expression & CD80/CD86 & Inhibit T-cell responses & {$[46,47,51,52]$} \\
\hline sCD80 (sB7-1) & Homodimer & $\begin{array}{l}\text { Unstimulated monocytes/B } \\
\text { cells }\end{array}$ & mRNA expression & CTLA-4 /CD28 & $\begin{array}{l}\text { Inhibit PD-1/PD-L1 } \\
\text { pathway }\end{array}$ & {$[53,54,56,59,60]$} \\
\hline sCD86 (sB7-2) & Monomer & Resting monocytes/DCs & $\begin{array}{l}\text { Cleavage of } \\
\text { membrane-bound } \\
\text { proteins/mRNA } \\
\text { expression }\end{array}$ & CTLA-4 & Inhibit T-cell responses & {$[65,69]$} \\
\hline sB7-H3 & Unknown & $\begin{array}{l}\text { Monocytes/ DCs/activated } \\
\text { T cells }\end{array}$ & $\begin{array}{l}\text { Cleavage of } \\
\text { membrane-bound } \\
\text { proteins/mRNA } \\
\text { expression }\end{array}$ & $\mathrm{B} 7-\mathrm{H} 3 \mathrm{R}$ & $\begin{array}{l}\text { Promote IL-8 and } \\
\text { VEGF expression }\end{array}$ & {$[70,71,77]$} \\
\hline sCD137 (s4-1BB) & Unknown & Activated PBMCs & $\begin{array}{l}\text { Cleavage of } \\
\text { membrane-bound } \\
\text { proteins/mRNA } \\
\text { expression }\end{array}$ & CD137L & $\begin{array}{l}\text { Inhibit CD137/CD137L } \\
\text { pathway }\end{array}$ & {$[78,79,82]$} \\
\hline
\end{tabular}

For example, sPD-1 has been reported to be a monomer, and it can be produced by PBMCs through mRNA expression. Moreover, sPD-1 can combine with PD-L1 and PD-L2, thus blocking PD-L/PD-1 interactions and somehow activating CD8+ T cells. Some soluble receptors can be produced by the cleavage of membranebound proteins or by both the cleavage of membrane-bound proteins and mRNA expression

adenovirus to transduce the thymidine kinase gene and sPD-1 into tumors, which causes tumor regression by upregulating the activation of $\mathrm{CD}^{+}{ }^{+} \mathrm{T}$ cells [24]. Moreover, in research on cancer treatments using a combination of the HSP70 vaccine and SPD-1, it has been found that SPD-1 can not only block PD-L1 but also reduce the expression of IL-10 gene, a negative regulatory gene [25]. Fibronectin $\mathrm{CH} 50$ has been demonstrated to increase the activity of macrophages, and in vivo studies have demonstrated that a sPD-1-CH50 recombinant peptide increases the cytolytic activity of both macrophages and cytotoxic $\mathrm{T}$ lymphocytes, especially towards PD-L1-positive tumor cells. This effect is due to the increased production of inducible nitric oxide synthase, TNF- $\alpha$ (tumor necrosis factor- $\alpha$ ), and IFN- $\gamma$ [26]. In addition, the combination of 4-1BBL and sPD-1 decreases the expression of IL-10 and TGF- $\beta$ in treated mice, thus inducing the expression of IL-2 and IFN- $\gamma$ and the accumulation of CD8+ $\mathrm{T}$ cells in the TME. Furthermore, one research team constructed a recombinant eukaryotic expression plasmid encoding SPD-1 to investigate the effects of a blockade of sPD-1/PD-L1 interaction, the antitumor response of T cells to SPD-1 and the local therapeutic effect of sPD-1 on mouse hepatocarcinoma. After coculturing sPD-1 with tumor cells (H22 cell line) and spleen lymphocytes, the group demonstrated a dual effect of sPD-1: an enhancement of the immune response through interaction with immune cells such as DCs and a blockade of PD-L1 on tumor cells [27].

Above all, we can speculate that SPD-1 can interact with PD-L1 and prevent PD-1 from combining with PD-L1; in other words, sPD-1 competes with PD-1 in vivo [28]. However, Harmjan Kuipers, et al. reported a different phenomenon. They cocultured DCs and T cells with sPD-1 and observed an inhibition of T cell proliferation and IL-2 production. They speculated that reverse signaling may take place when SPD-1 binds to PD-L1 on DCs (see Fig. 2) [29].

\section{Treatment methods}

Thus far, some treatments using sPD-1 have been tested in mice, but the use of this treatment has not been reported in humans. However, mouse models can provide insight to improve future antitumor treatments for humans. It has been reported that when the HSP70 vaccine and SPD-1-which are used to treat cancer and to block PD-L1, respectively-are combined, mice experience a significantly prolonged survival time compared to mice treated with HSP70 or SPD-1 separately [25]. In China, researchers used naked plasmids to deliver SPD-1-CH50 into tumor inoculation sites and 


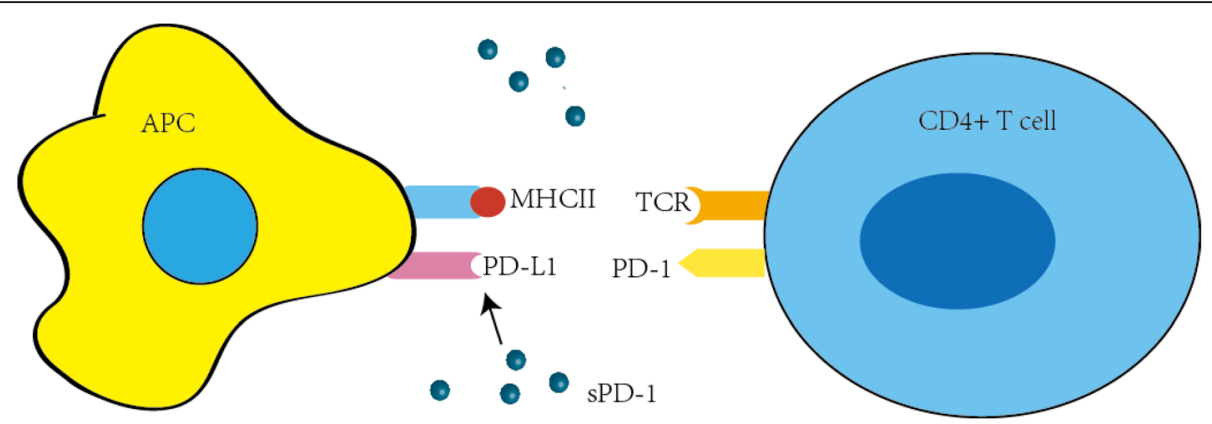

Fig. 2 The role of SPD-1 between APCs and T cells. Some studies have demonstrated that when SPD-1 binds to PD-L1 in APCS, it can induce a reverse signal that acts on APCs and inhibits T cell function. However, other experiments have found that the existence of PD-L1/SPD-1 enhances the function of T cells. T cells can be activated with the anti-PD-L1-mAb

found that SPD-1-CH50 stimulates more effective antitumor activity than sPD-1, CH50 or sPD-1/CH50, which shows that the recombinant protein SPD-1-CH50 can be used as a therapeutic strategy after the surgical removal of tumors [26]. Moreover, after researchers administered sPD-1 DNA with the human papilloma virus-16 E7 DNA vaccine to mice, E7-specific $\mathrm{CD} 8^{+} \mathrm{T}$ cell responses were significantly enhanced, resulting in potent antitumor effects against E7-expressing tumors and causing a significant increase in the survival rate up to $75 \%$; this suggests a role for sPD-1 DNA as a genetic adjuvant and for prophylactic antitumor treatment [23]. In mice with H22 hepatocarcinoma, naked plasmid of 4-1BBL and sPD-1 were injected for local gene transfer; ultimately, this treatment completely eradicated tumors from mice with small numbers of preexisting tumor cells and eradicated tumors from $60 \%$ of individuals with larger numbers of preexisting tumor cells [30].

\section{SPD-L1}

\section{Production}

sPD-L1 can be produced and released by both tumor cells and activated mature DCs, while immature DCs, macrophages, monocytes and $\mathrm{T}$ cells are refractory to releasing sPD-L1 [31]. sPD-L1 is detectable in human serum, and its concentration increases with age; furthermore, it has been reported that increased MMPI (matrix metalloproteinase inhibitor) reduces the production of SPD-L1 in PD-L1 transfected cells, suggesting that sPD-L1 may be produced by the proteolytic cleavage of membrane-bound proteins [32]. PD-L1 is encoded by the CD274 gene which comprises seven exons on chromosome 19 in mice and on chromosome 9 in humans. However, evidence that SPD-L1 can be produced by alternative splicing has not been found [33].

\section{Prognosis}

In a French multicenter randomized phase III clinical trial, researchers found that the levels of sPD-L1 in the plasma of patients with DLBCL (diffuse large B-cell lymphoma) were much higher than healthy humans. These patients were treated with high-dose chemotherapy and rituximab. Then, patients with elevated SPD-L1 experienced poorer prognosis, with a 3-year OS rate of $76 \%$ versus $89 \%$ in healthy individuals. When patients were in CR (complete remission), their sPD-L1 levels returned to normal [34]. In a clinical study about malignant melanoma, early changes in sPD-L1 levels after checkpoint blockade treatment did not correspond with benefit. However, rise in sPD-L1 after 5 months of treatment correlated with partial responses in ipilimumabtreated patients. And rise in sPD-L1 after pembrolizumab treatment was also associated with partial responses, and high pre-treatment levels were associated with disease progression [35]. For nivolumab-treated patients with NSCLC, lower basal plasma levels of SPD-L1 were associated with better clinical benefit, but the changes during treatment were still vague [36]. In another study on 141 patients with HBV-related HCC, circulating PD-L1 expression was closely related to intratumoral PD-L1 expression and PD-1/PD-L1 expression was associated with tumor size, blood vessel invasion and BCLC (Barcelona Clinic Liver Cancer) stage. Moreover, patients with higher expression of circulating PD-L1 and PD-1 had shorter OS and tumor-free survival times than those with lower expression. These results show that patients with higher SPD-1 and SPD-L1 levels have a worse prognosis [37]. In a study on NKTCL (natural killer/T-cell lymphoma), patients with a high concentration of serum sPD-L1 $(\geq 3.4 \mathrm{ng} / \mathrm{ml})$ or with a high percentage of PD-L1 expression in tumor specimens $(\geq 38 \%)$ responded poorly to treatment and exhibited markedly worse survival than patients with lower concentrations or lower percentages of expression. Furthermore, a high concentration of serum SPD-L1 and a high percentage of PD-L1 expression in tumor specimens can be independent adverse prognostic factors in patients with stage I II NKTCL 
[38]. Similar to the study above, studies by both Wang and Huang's teams found that the overall response rate to treatment was higher in low SPD-L1 patients than in high sPD-L1 patients with MM (multiple myeloma), indicating a poorer prognosis in patients with higher levels of sPD-L1 (> $2.783 \mathrm{ng} / \mathrm{mL})[39,40]$. In patients with oral squamous cell carcinoma, the increased expression of sPD-L1 has also been found to be associated with poor prognosis [41]. Similarly, in HL (Hodgkin Lymphoma), sPD-L1 levels are positively correlated with clinical stage [42]. However, the phenomenon in advanced gastric cancer seemed to be contradictory to the above researches, in which adenocarcinoma patients with higher PD-L1 expression had much better prognosis and less lymph node metastasis than low-expression patients [43].

\section{Biological mechanism}

A study on the role of sPD-L1 found that IFN- $\gamma$ secretion by CLL (chronic lymphocytic leukemia) T lymphocytes decreases significantly in the presence of SPD-L1. Conversely, treatment with an anti-PD-L1 antibody leads to a significant increase in IFN- $\gamma$ secretion by CLL T lymphocytes [44], and coincubation of CD4+ or CD8+ T cells with sPD-L1-producing cells and $\mathrm{mDC}$-derived sPD-L1 induces $\mathrm{T}$ cells to undergo apoptosis [31]. As sPD-L1 spreads throughout the body via the blood and lymphatic circulation, it exerts a widespread inhibitory effect by interacting with cell surface receptors such as membrane-bound PD-1 [44].

\section{SPD-L2}

Two novel human PD-L2 splice variants have been identified. In the major variant, exon 3 is cut off, and the protein product lacks the IgC-like domain and is shorter in the extracellular region. Although the other variant is also generated by cutting off exon 3, the acceptor site for that variant is $5 \mathrm{bp}$ downstream of the canonical acceptor site. This second variant also has a frameshift such that its protein product lacks the transmembrane domain and is secreted in a soluble form, which is thought to be sPD-L2. These findings suggest that sPD-L2 expression may be controlled by posttranscriptional regulation through alternative splicing [45].

\section{sCTLA-4}

\section{Production}

Although the prominent source of sCTLA-4 is Treg cells, the sCTLA- 4 transcripts have also been detected in both monocytes and immature DCs [46]. Magistrelli et al. identified an additional splice variant named CTLA-4delTM that lacks both the transmembrane and intracellular domains. The splice variant, derived from the deletion of exon 2 (which encodes the transmembrane domain and the cytoplasmic tail of CTLA-4), is thought to be translated into sCTLA-4. Furthermore, CTLA-4delTM can be produced as a soluble monomer [47].

\section{Prognosis}

There have been only a few reports on sCTLA-4 levels in the serum of patients with cancer. In a study, for ipilimumab-treated patients with melanoma, those who could respond to the treatment had higher serum levels of sCTLA-4 $($ mean $=2417 \mathrm{pg} / \mathrm{mL})$ and experienced longer OS [48]. In addition, recent analyses of primary melanoma cell lines have demonstrated that the cells can secrete detectable levels of sCTLA-4, supporting the relevance of this molecule in cancer. And in B-ALL (B-cell acute lymphoblastic leukemia) patients, the correlation between SCTLA-4 and neoplastic B cells was apparently negative [49]. Furthermore, it has been shown that sCTLA-4 is expressed by malignant B cells, at least in pediatric ALL patients, and the release of sCTLA-4 from acute lymphoblastic leukemia cells may constitute a strategy for immune-surveillance escape [50].

\section{Biological mechanism}

Analysis of human $\mathrm{T}$ cells in vitro has shown that sCTLA-4 secretion can increase during immune responses and has potent inhibitory properties, as isoform-specific blockade of sCTLA-4 significantly increases Ag(antigen)-driven proliferation and cytokine (IFN- $\gamma$, IL-17) secretion [46]. Similar to full-length CTLA-4, sCTLA-4 can bind to B7 costimulatory ligands on APCs to prevent B7 from combining with the costimulatory receptor $\mathrm{CD} 28$ in $\mathrm{T}$ cells, thus inhibiting T-cell responses. Furthermore, sCTLA-4 can neutralize the anti-CTLA-4-mAb in vivo. Indeed, the inhibition of sCTLA-4 with anti-sCTLA$4-\mathrm{mAb}$ induces significant increases in antigen-specific immune responses both in vitro and in vivo. In human peripheral blood mononuclear cell responses, the selective blockade of sCTLA- 4 activates the proliferation of $\mathrm{CD}^{+}$ and $\mathrm{CD} 4^{+} \mathrm{T}$ cells and promotes increased cytokine secretion, most notably the secretion of IFN- $\gamma$, which in turn enhances antitumor effects [51]. As is the case for sPD-1, the affinity of sCTLA-4/CD80 has not been reported. However, CTLA-4 binds to CD80 and CD86 with Kd values of $0.2 \mu \mathrm{M}$ and $2.6 \mu \mathrm{M}$ respectively, which are approximately 10 -fold lower than the $\mathrm{Kd}$ values for the binding of CD28 to CD80 and CD86 $(4 \mu \mathrm{M}$ and $20 \mu \mathrm{M}$, respectively) [52].

\section{Treatment methods}

Thus far, there have been few studies on the implications of SCTLA-4 in cancer treatment. With regards to anti-CTLA-4-mAbs, it is interesting that selective blockade of sCTLA-4 can not only enhance antigen-specific $\mathrm{CD} 4^{+}$and $\mathrm{CD} 8^{+} \mathrm{T}$-cell responses but also exert functional antitumor activity without 
requiring an interaction with full length CTLA-4 in a murine model of melanoma [51].

\section{sCD80}

\section{Production}

CD80 is a costimulatory factor mainly expressed on the surface of activated monocytes, B cells and DCs. Kakoulidou et al. found that a spliced form, sCD80, is expressed in unstimulated monocytes and $\mathrm{B}$ cells. sCD80 lacks the transmembrane domain and can bind to recombinant CD152-Ig, CD28-Ig and activated T cells [53]. sCD80 is thought to be a homodimer based on an analysis of its structure [54].

\section{Prognosis}

In one clinical study, the sCD80 levels in the majority of patients with AML (acute myeloid leukemia) (13/17) and MM (11/12) were normal. However, significantly elevated levels were detected in CLL and MCL (mantle cell lymphoma) patients. Furthermore, increased sCD80 levels in CLL patients were significantly associated with poor prognosis and were accompanied by low platelet and hemoglobin levels with elevated WBC counts and the expression of CD38 [55].

\section{Biological mechanism}

Kakoulidou et al. reported that recombinant sCD80 has immunomodulatory effects, as shown by its inhibition of the mixed lymphocyte reaction and T-cell proliferation; they speculated that the preferential binding of $\mathrm{sCD} 80$ to CD152 is responsible for the inhibitory reaction [53]. In contrast, Wei et al. posited that soluble B7-IgG can bind to CTLA-4 on activated T cells with a high affinity, blocking the negative signals triggered by $\mathrm{SCD} 80$ - which is different from the response triggered by membranebound CD80 [56]. Furthermore, Sturmhoefel et al. found that soluble B7-IgG can induce T-cell proliferation in therapy for established tumors [57]. More concrete mechanisms have since been studied. For example, one study found that a soluble form of CD80, CD80-Fc (in which the extracellular domains of human or mouse CD80 are fused to the Fc domain of IgG1), increased the production of IFN- $\gamma$ by $\mathrm{PD}-1^{+}$activated $\mathrm{T}$ cells more effectively than antibodies to PD-1 or PD-L1, possibly by neutralizing PD-L1 or costimulating with CD28 [58]. Suzanne et al. and Samuel et al. achieved similar results, finding that $\mathrm{CD} 80-\mathrm{Fc}$ could sustain IFN- $\gamma$ production by both human and murine PD- $1^{+}$ activated $\mathrm{T}$ cells in the presence of $\mathrm{PD}-\mathrm{L}^{+}$human or mouse tumor cells, respectively. They also found that CD80-Fc simultaneously inhibited PD-L1/PD-1-mediated immune suppression $[59,60]$.

\section{Treatment methods}

In a preclinical study, the CD80-Fc was used in combination with Treg cell depletion, which dramatically controlled the colon tumor size and enhanced antitumor activity. Furthermore, the mice in the study exhibited immunologic memory since they can reject subsequent implants in rechallenge experiments [61]. In another study, the CD80-Fc fusion protein gene was delivered to tumor cells in vivo in the context of an oncolytic replication-competent herpes simplex virus [62]. However, Zhou et al. described a nonviral intramuscular gene transfer method to deliver this therapeutic protein, after which muscle tissue can exert immune costimulatory effects for cancer therapy by producing the protein in large quantities. This gene transfer method has also been used as an adjuvant therapy for DNA vaccination [63]. Combination therapy has also been considered. For example, Yasushi et al. combined IL-12, IL-18, and SCD80 with oncolytic herpes simplex virus-1 vectors in a treatment and showed strong antitumor activity [64].

\section{sCD86}

\section{Production}

sCD86 is produced by resting monocytes in human beings. Jeannin et al. demonstrated that the sCD86 detected in human serum can be generated by the translation of the CD86 ${ }^{\triangle} \mathrm{TM}$ mRNA, which is characterized by the deletion of the transmembrane domain. And sCD86 is formed as a monomer [65].

\section{Prognosis}

Hock et al. reported that the plasma of a proportion of examined leukemia patients contained elevated levels of sCD86, but the sCD86 levels were not directly related to CRP (C-reactive protein)levels, suggesting that increases in $\mathrm{SCD} 86$ are not solely related to a broad inflammatory response. Furthermore, no relationship between sCD86 levels and prognosis was found [66]. In another study, levels of sCD86 were elevated $(>2.32 \mathrm{ng} / \mathrm{mL})$ relative to normal donors in $25 \%$ of patients with AML and in $27 \%$ of patients with MDS (myelodysplastic syndrome). In addition, compared to AML patients with normal sCD86 levels, patients with AML who had elevated sCD86 levels experienced significantly lower CR rates and poorer survival. However, the correlation between sCD86 levels and CR rates or survival rates in patients with MDS was not found [67].

In 299 patients from the UK Medical Research Council myeloma VIth trial, Hock et al. reported that serum levels of sCD86 were significantly elevated. They also found that elevated sCD86 levels were associated with significantly shorter survival (median $=22$ vs. 51 months) and event-free survival times (median $=14$ vs. 31 months) in $\mathrm{ABCM}+\mathrm{P}$ patients (patients receiving adriamycin, 
carmustine, cyclophosphamide, and melphalan with prednisolone), which suggested that $\mathrm{sCD} 86$ may be an important prognosis marker in at least some myeloma treatment groups [68].

\section{Biological mechanism}

There have been few reports on the function of sCD86 in serum. Juan et al. found that co-delivery of sCD86 downregulated the immune response to a DNA vaccine, suggesting that sCD86 may bind to CTLA-4 to transfer a negative signal to $\mathrm{T}$ lymphocytes [69].

\section{sB7-H3}

\section{Production}

Zhang et al. demonstrated that sB7-H3 is released by monocytes, DCs, activated $\mathrm{T}$ cells, and various $\mathrm{mB} 7-\mathrm{H}^{+}$ (membrane $\mathrm{B} 7-\mathrm{H}^{+}$) cells but not by $\mathrm{mB} 7-\mathrm{H}^{-}{ }^{-}$carcinoma cells. After the addition of MMPI, the release of sB7-H3 from cells is blocked, indicating that the release of sB7-H3 from B7-H3 on the cell surface is mediated by a matrix metalloproteinase [70]. Moreover, Chen et al. found that $\mathrm{sB} 7-\mathrm{H} 3$ is also generated by alternative splicing of mRNA [71].

\section{Prognosis}

In one study conducted by a single center, the expression of sB7-H3 and sPD-L1 in the CSF (cerebrospinal fluid) of the patients with glioma was higher than the patients with a moderate traumatic brain injury. Furthermore, the expression of B7-H3 and PD-L1 in CSF and tumor tissues was related to the glioma grade [72]. In clear cell renal cell carcinoma, both the serum level of sB7-H3 and sIL-2R (soluble IL-2R) are significantly correlated with the clinical stage, and the level of sB7-H3 shows a positive correlation with sIL-2R [73]. In a study, sB7-H3 concentrations were significantly higher in patients with ESHCC (early-stage hepatocellular carcinoma) than in cirrhotic patients $(60.79 \pm 19.45 \mathrm{ng} / \mathrm{mL}$ vs. $32.33 \pm 11.52 \mathrm{ng} / \mathrm{mL}$ ). Furthermore, high levels of sB7-H3 were correlated with poor clinical outcomes [74]. Chen et al. measured the expression of sB7-H3 in NSCLC-derived MPEs (malignant pleural effusions) and found that the median value of $\mathrm{sB} 7-\mathrm{H} 3$ in 52 MPEs was higher than that in 47 NPEs (nonneoplastic pleural effusions). Moreover, the levels of MPE-derived sB7-H3 were correlated with smoking status, primary tumor size ( $\mathrm{T}$ factor), regional lymph node dissemination ( $\mathrm{N}$ factor) and distant metastasis (M factor) in NSCLC patients, suggesting that increased sB7-H3 in MPEs is correlated with the TNM stage of NSCLC [75].

\section{Biological mechanism}

sB7-H3 can bind to the B7-H3R (B7-H3 receptor) on activated $\mathrm{T}$ cells, showing that $\mathrm{sB} 7-\mathrm{H} 3$ is functional [70]. In Chen et al.'s study, $\mathrm{T}$ cell proliferation was significantly inhibited in the presence of sB7-H3 compared to the control group, and sB7-H3 significantly reduced the levels of both IL- 2 and INF- $\gamma$ in the culture supernatants compared to the levels in the control group, suggesting that $\mathrm{sB} 7-\mathrm{H} 3$ can negatively regulate $\mathrm{T}$ cell responses [71]. Sun et al. found that sB7-H3 can induce macrophages to increase the expression of MMR (macrophage mannose receptor) and IL-10 and decrease the expression of HLA(human leukocyte antigen)-DR and IL- $1 \beta$ in vitro, which can switch the macrophage phenotype from M1 to M2 [76]. Xie et al. observed that sB7-H3 was highly expressed in $\mathrm{mB} 7-\mathrm{H}^{+}$pancreatic carcinoma cells. Additionally, sB7-H3 promoted IL-8 and VEGF expression by first increasing TLR4 expression and then activating NF- $\mathrm{kB}$ signaling, which facilitated the formation of nascent blood vessels to help the cancer cells invade and metastasize [77].

\section{sCD137}

\section{Production}

Similar to murine sCD137, human sCD137 is generated by alternative mRNA splicing [78]. One study found that sCD137 can be generated by PBMCs; notably, the expression of $\mathrm{sCD} 137$ in lymphocytes requires strong activation, and the levels of SCD137 negatively correlate with lymphocyte proliferation and positively correlate with the degree of activation-induced cell death caused by mitogen overstimulation [79].

\section{Prognosis}

According to a small single-center study, patients with colon cancer have significantly higher plasma levels of sCD137 than patients with rectal cancer $(3931 \pm 1268$ $\mathrm{pg} / \mathrm{ml}$ vs. $1194 \pm 581 \mathrm{pg} / \mathrm{ml}$ ). Interestingly, the levels of sCD137 and sCD137L are significantly correlated, indicating that divergent mechanisms might be involved in the pathogenesis of colorectal cancer [80]. Enhanced levels of sCD137 can be detected in the sera of patients with leukemia and lymphoma, and high sCD137 levels are strongly associated with CLL. However, why sCD137 is present in only a proportion of patients and whether sCD137 levels correlate with other parameters-such as disease stage, disease progression or therapeutic success-remain unclear [81].

\section{Biological mechanism}

Labiano et al. induced tumor cells to generate sCD137 with hypoxia and demonstrated that tumor-secreted sCD137 prevents the costimulation of 
Table 2 Serum/plasma levels of soluble receptors and ligands detected in different types of diseases and their correlations with prognosis or outcomes

\begin{tabular}{|c|c|c|c|c|c|c|}
\hline $\begin{array}{l}\text { Soluble } \\
\text { receptor/ligand }\end{array}$ & Related diseases & $\begin{array}{l}\text { Number } \\
\text { of patients }\end{array}$ & $\begin{array}{l}\text { Type } \\
\text { of analyses }\end{array}$ & $\begin{array}{l}\text { Serum/plasma } \\
\text { levels }\end{array}$ & Prognosis/outcomes & References \\
\hline \multirow[t]{8}{*}{ SPD-1 } & $\mathrm{HCC}$ & $n=126$ & Multivariate & + & $\begin{array}{l}\text { High levels of viral load and } \\
\text { SPD-1 associated with increase } \\
\text { in risk of HCC }\end{array}$ & {$[22]$} \\
\hline & $\begin{array}{l}\text { RA (Rheumatoid } \\
\text { arthritis) }\end{array}$ & $n=95$ & 1 & + & 1 & {$[85]$} \\
\hline & & $n=82$ & 1 & - & 1 & {$[86]$} \\
\hline & $\begin{array}{l}\text { ITP (Immune } \\
\text { thrombocytopenia) }\end{array}$ & $n=67$ & 1 & - & 1 & {$[87]$} \\
\hline & $\begin{array}{l}\text { HCV (Hepatitis } \\
\text { C virus) infection }\end{array}$ & $n=63$ & 1 & + & 1 & {$[88]$} \\
\hline & AA (Aplastic anemia) & $n=80$ & 1 & + & 1 & [89] \\
\hline & Sepsis & $n=112$ & Multivariate & + & $\begin{array}{l}\text { High levels associated with } \\
\text { higher } 28 \text {-day mortality }\end{array}$ & {$[90]$} \\
\hline & $\begin{array}{l}\text { ARDS (Acute } \\
\text { respiratory distress } \\
\text { syndrome) }\end{array}$ & $n=10-13$ & 1 & + & 1 & [91] \\
\hline \multirow[t]{8}{*}{ sPD-L1 } & DLBCL & $n=288$ & $\begin{array}{l}\text { Multivariate/ } \\
\text { univariate }\end{array}$ & + & $\begin{array}{l}\text { Elevated SPD-L1 experienced } \\
\text { a poorer 3-year OS }\end{array}$ & [34] \\
\hline & NKTCL & $n=77$ & $\begin{array}{l}\text { Multivariate/ } \\
\text { univariate }\end{array}$ & + & $\begin{array}{l}\text { High concentration associated } \\
\text { with shorter survival }\end{array}$ & {$[38]$} \\
\hline & $\begin{array}{l}\text { Oral squamous } \\
\text { cell carcinoma }\end{array}$ & $n=82$ & Univariate & + & $\begin{array}{l}\text { Higher levels associated with } \\
\text { lower tumor cell differentiation }\end{array}$ & {$[41]$} \\
\hline & $\mathrm{HL}$ & $n=108$ & Multivariate & + & $\begin{array}{l}\text { Higher levels associated with } \\
\text { shorter progression-free survival }\end{array}$ & {$[42]$} \\
\hline & $\begin{array}{l}\text { CE (Cystic } \\
\text { echinococcosis) }\end{array}$ & $n=51$ & 1 & + & 1 & {$[44]$} \\
\hline & AR (Allergic rhinitis) & $n=90$ & Univariate & - & $\begin{array}{l}\text { Lower levels associated with } \\
\text { lower disease severity }\end{array}$ & [92] \\
\hline & $\begin{array}{l}\text { T1DM (Type } 1 \\
\text { diabetes mellitus) }\end{array}$ & $n=176$ & 1 & - & 1 & [93] \\
\hline & $\begin{array}{l}\text { T2DM (Type } 2 \\
\text { diabetes mellitus) }\end{array}$ & $n=125$ & Univariate & + & $\begin{array}{l}\text { Higher levels associated with } \\
\text { increased severity of diabetic } \\
\text { atherosclerotic macrovascular diseases }\end{array}$ & [94] \\
\hline SPD-L2 & SSc (Systemic sclerosis) & $n=91$ & Univariate & + & $\begin{array}{l}\text { Higher levels associated worse } \\
\text { pulmonary fibrosis }\end{array}$ & [95] \\
\hline \multirow[t]{5}{*}{ sCTLA-4 } & B-ALL & $\mathrm{n}=80$ & 1 & + & 1 & {$[50]$} \\
\hline & RA & $n=56$ & Univariate & + & $\begin{array}{l}\text { Higher levels associated with } \\
\text { higher disease activity }\end{array}$ & [96] \\
\hline & Chronic hepatitis & $n=81$ & 1 & + & 1 & [97] \\
\hline & T1DM & 1 & 1 & + & 1 & [98] \\
\hline & $\begin{array}{l}\text { SpA } \\
\text { (Spondyloarthropathies) }\end{array}$ & $n=165$ & Univariate & + & $\begin{array}{l}\text { Higher levels associated with } \\
\text { higher disease activity }\end{array}$ & [99] \\
\hline \multirow[t]{3}{*}{ sCD80 } & $C L L$ & $n=34$ & Univariate & + & $\begin{array}{l}\text { Higher levels associated with } \\
\text { poorer prognosis }\end{array}$ & {$[55]$} \\
\hline & RA & $n=56$ & Univariate & + & $\begin{array}{l}\text { The levels did not correlate } \\
\text { with disease activity }\end{array}$ & [96] \\
\hline & Acute asthma & $n=16$ & 1 & + & 1 & {$[100]$} \\
\hline \multirow[t]{3}{*}{ sCD86 } & Leukemia & $n=24$ & 1 & + & 1 & {$[66]$} \\
\hline & AML & $n=57$ & Multivariate & + & $\begin{array}{l}\text { Higher levels associated with } \\
\text { shorter survival }\end{array}$ & {$[67]$} \\
\hline & Myeloma & $n=299$ & Multivariate/ & + & Higher levels associated with & {$[68]$} \\
\hline
\end{tabular}


Table 2 Serum/plasma levels of soluble receptors and ligands detected in different types of diseases and their correlations with prognosis or outcomes (Continued)

\begin{tabular}{|c|c|c|c|c|c|c|}
\hline $\begin{array}{l}\text { Soluble } \\
\text { receptor/ligand }\end{array}$ & Related diseases & $\begin{array}{l}\text { Number } \\
\text { of patients }\end{array}$ & $\begin{array}{l}\text { Type } \\
\text { of analyses }\end{array}$ & $\begin{array}{l}\text { Serum/plasma } \\
\text { levels }\end{array}$ & Prognosis/outcomes & References \\
\hline & & & univariate & & $\begin{array}{l}\text { shorter survival in } \mathrm{ABCM}+ \\
\mathrm{P} \text { patients }\end{array}$ & \\
\hline & RA & $n=35$ & $\backslash$ & + & 1 & [101] \\
\hline & $\begin{array}{l}\text { SLE (Systemic } \\
\text { lupus erythematosus) }\end{array}$ & $n=79$ & $\backslash$ & + & 1 & [102] \\
\hline & Acute asthma & $n=16$ & $\backslash$ & + & 1 & [100] \\
\hline & & $n=68$ & $\backslash$ & + & $\begin{array}{l}\text { Higher levels associated with } \\
\text { acute asthma exacerbation }\end{array}$ & [103] \\
\hline \multirow[t]{7}{*}{ sB7-H3 } & Glioma & $n=78$ & Univariate & $\backslash$ & $\begin{array}{l}\text { Higher levels associated with } \\
\text { high-grade glioma }\end{array}$ & [72] \\
\hline & ESHCC & $n=149$ & $\begin{array}{l}\text { Multivariate/ } \\
\text { univariate }\end{array}$ & + & $\begin{array}{l}\text { Higher levels associated with } \\
\text { lower survival rate }\end{array}$ & [74] \\
\hline & Sepsis & $n=27$ & Univariate & + & $\begin{array}{l}\text { Higher levels associated with } \\
\text { a poor outcome }\end{array}$ & [104] \\
\hline & Chronic prostatitis & $n=91$ & $\backslash$ & $\backslash$ & 1 & [105] \\
\hline & $\begin{array}{l}\text { MS (Multiple } \\
\text { sclerosis) }\end{array}$ & $n=32$ & Univariate & - & $\begin{array}{l}\text { Lower levels associated with } \\
\text { a poorer outcome }\end{array}$ & [106] \\
\hline & $\begin{array}{l}\text { CHB (Chronic } \\
\text { HBV infection) }\end{array}$ & $n=136$ & Univariate & + & $\begin{array}{l}\text { Increased levels associated with } \\
\text { the progression of liver cirrhosis }\end{array}$ & [107] \\
\hline & SLE & $n=78$ & Univariate & - & $\begin{array}{l}\text { Higher levels associated with } \\
\text { higher disease activity }\end{array}$ & [108] \\
\hline \multirow[t]{7}{*}{ sCD137 } & Colon cancer & $n=76$ & 1 & + & $\backslash$ & [80] \\
\hline & $\begin{array}{l}\text { Leukemia } \\
\text { and lymphoma }\end{array}$ & $n=173$ & $\backslash$ & + & $\backslash$ & [81] \\
\hline & Acute pancreatitis & $n=41$ & Univariate & + & $\begin{array}{l}\text { Higher levels associated with } \\
\text { a poor outcome }\end{array}$ & [109] \\
\hline & $\begin{array}{l}\text { ACS (acute } \\
\text { coronary syndrome) }\end{array}$ & $n=180$ & Multivariate & + & $\begin{array}{l}\text { Higher levels associated with } \\
\text { increased risk for adverse } \\
\text { cardiovascular events }\end{array}$ & [110] \\
\hline & Multiple sclerosis & $n=26$ & Univariate & + & $\begin{array}{l}\text { Higher levels associated with } \\
\text { higher disease activity }\end{array}$ & [111] \\
\hline & RA & $n=30$ & Univariate & + & $\begin{array}{l}\text { Higher levels associated with } \\
\text { higher disease severity }\end{array}$ & [112] \\
\hline & $\begin{array}{l}\text { Acute } \\
\text { atherothrombotic } \\
\text { stroke }\end{array}$ & $n=27$ & $\backslash$ & + & $\backslash$ & [113] \\
\hline
\end{tabular}

Such studies supply information for the formulation of therapeutic strategies. The type of analyses refers to the way of analysis of the associations between levels and prognosis or outcomes. + means higher than controls; - means lower than controls; \in serum/plasma levels means no significant difference between patients and controls, $\backslash$ in types of analyses and prognosis/outcomes means no data found

$\mathrm{T}$ lymphocytes by preventing the interaction of CD137L with the transmembrane forms of CD137 expressed on $\mathrm{T}$ lymphocytes [82].

\section{Treatment methods}

In one study, breast cancer cells were treated with sCD137 in combination with SAHA (suberoylanilide hydroxamic acid), and the synergistic cytotoxic effect was enhanced, suggesting that a combination of SAHA and sCD137 could be a potential cancer therapy [83].

\section{Conclusions and future perspectives}

The natural soluble forms of receptors and ligands are important components of immune regulation, although their definitive mechanisms of action have not been determined. In this review, we selected sPD-1, sPD-L1, sPD-L2, sCTLA-4, sCD80, sCD86, sB7-H3 and sCD137 for analysis. All of these molecules may play important roles in cancer. Many studies regarding these entities are ongoing, and the relevance of soluble receptors and ligands to various diseases is becoming increasingly apparent. As soluble molecules, their serum and tissue 
Table 3 Biomarkers for clinical outcomes under target therapy for cancer patients

\begin{tabular}{|c|c|c|c|c|c|c|}
\hline Biomarker & Cancer & $\begin{array}{l}\text { Number } \\
\text { of patients }\end{array}$ & Treatment & $\begin{array}{l}\text { Level changes } \\
\text { during treatment }\end{array}$ & Outcomes & References \\
\hline sPD-1 & NSCLC & $n=38$ & Erlotinib & Uncertain & $\begin{array}{l}\text { Higher treatment levels associated } \\
\text { with prolonged progression-free } \\
\text { and overall survival }\end{array}$ & [21] \\
\hline \multirow[t]{3}{*}{ sPD-L1 } & DLBCL & $n=288$ & $\begin{array}{l}\text { High-dose chemotherapy + } \\
\text { rituximab }\end{array}$ & Uncertain & $\begin{array}{l}\text { High pre-treatment levels associated } \\
\text { with poorer prognosis }\end{array}$ & [34] \\
\hline & $\begin{array}{l}\text { Malignant } \\
\text { melanoma }\end{array}$ & $n=251$ & $\begin{array}{l}\text { Ipilimumab ( } \pm \text { bevacizumab } \\
\text { or sargramostim), } \\
\text { pembrolizumab }\end{array}$ & Uncertain & $\begin{array}{l}\text { High pre-treatment levels associated } \\
\text { with disease progression }\end{array}$ & [35] \\
\hline & NSCLC & $n=39$ & Nivolumab & Uncertain & $\begin{array}{l}\text { Lower basal plasma levels associated } \\
\text { with better clinical benefit }\end{array}$ & {$[36]$} \\
\hline sCTLA-4 & Melanoma & $n=14$ & Ipilimumab & Not mentioned & $\begin{array}{l}\text { Higher SCTLA4 in responders, } \\
\text { associated with longer OS }\end{array}$ & [48] \\
\hline
\end{tabular}

Such studies supply information for the formulation of diagnostic tools. Uncertain means the levels may be as same as control or be higher or lower than control

in the study; not mentioned means no data found in the study

levels can be easily detected. These molecules may also be critical factors for evaluating the severity and prognosis of cancer and many other diseases since most patients experience changes in their levels (See Table 2); in addition, some soluble molecules have been reported to be predictive markers for the benefit of target therapy (See Table 3). In immunotherapy, immunogenicity of checkpoint inhibitors is still a severe problem, and the detection of anti-drug antibodies is still equated as a main way to measure immunogenicity [84]. According to the characteristics of soluble receptors, it is probable for them to neutralize the effect of monoclonal antibodies. Furthermore, whether they are included or paly important role in the hypersensitivity reactions during therapy is also unknown, since the interaction and changes of levels of these molecules are complicated. Thus, it is hopeful but there is a long way to find applicable soluble molecules to predict immunogenicity. Moreover, their exact functions are still unclear. Thus far, studies have developed methods to assess some of these proteins, such as SPD-1 and sCTLA-4. Thus, we can use these technologies for further research. In addition to detecting the proteins, some researchers have successfully mediated their serum levels to regulate the human immune system, suggesting that such manipulations can potentially be used in cancer treatment. Based on limited experimental and clinical findings, these soluble receptors and ligands can be novel therapeutic targets. Although it has been established that the concentrations of soluble receptors can influence the activation of APCs and T cells, the specific relevance of these factors is still unknown; nevertheless, we can use antibodies such as anti-PD-1-mAb and anti-CTLA4-mAb to block these targets and neutralize their various functions in the progression of diseases. However, it may be necessary-yet difficult-to find more specific antibodies to precisely mediate these targets since current antibodies cannot distinguish between full-length receptors and soluble receptors. Although it will be some time before the precise regulatory roles of these soluble receptors and ligands are illuminated, it is imperative that they are considered in the formation of strategies for immunotherapy.

\section{Abbreviations}

AA: Aplastic anemia; AML: Acute myeloid leukemia; APCs: Antigen-presenting cells; AR: Allergic rhinitis; ARDS: Acute respiratory distress syndrome; B7H3R: B7-H3 receptor; B-ALL: B-cell acute lymphoblastic leukemia; BCLC: Barcelona clinic liver cancer; CE: Cystic echinococcosis; CHB: Chronic HBV infection; CLL: Chronic lymphocytic leukemia; CR: Complete remission; CRP: C-reactive protein; CSF: Cerebrospinal fluid; CTLA-4: Cytotoxic Tlymphocyte-associated protein 4; DCs: Dendritic cells; ESHCC: Early-stage hepatocellular carcinoma; HCC: Hepatocellular carcinoma; HCV: Hepatitis C virus; HL: Hodgkin Lymphoma; HLA: Human leukocyte antigen; IFN$\gamma$ : Interferon- $\gamma ;$ ITP: Immune thrombocytopenia; mB7- $\mathrm{H3}^{+}$: Membrane $\mathrm{B} 7-\mathrm{H}^{+}$; MCL: Mantle cell lymphoma; MDS: Myelodysplastic syndrome; MHC: Major histocompatibility complex; MM: Multiple myeloma; MMPI: Matrix metalloproteinase inhibitor; MMR: Macrophage mannose receptor; MPEs: Malignant pleural effusions; MPP: Mycoplasma pneumoniae pneumonia; MS: Multiple sclerosis; NKTCL: Natural killer/T-cell lymphoma; NPEs: Nonneoplastic pleural effusions; NSCLC: Non-small cell lung cancer; OS: Overall survival; PBMCs: Peripheral blood mononuclear cells; PD1: Programmed cell death-1; PD-L1/2: Programmed cell death ligand-1/2, also known as B7-H1/2; RA: Rheumatoid arthritis; SAHA: Suberoylanilide hydroxamic acid; SCTLA-4: Soluble CTLA-4; IIL-2R: Soluble IL-2R; SLE: Systemic lupus erythematosus; SpA: Spondyloarthropathies; SPD-1: Soluble PD-1; SSc: Systemic sclerosis; T1DM: Type 1 diabetes mellitus; T2DM: Type 2 diabetes mellitus; TCR: T-cell receptor; TME: Tumor microenvironment; TNFa: Tumor necrosis factor-a

\section{Acknowledgments}

Not applicable.

\section{Funding}

This work was supported by the National Key R\&D Program (2018YFC1313400), the National Natural Science Foundation of China (NSFC, NO.81502434) and the Precision Medicine Foundation of Chongqing (No.cstc2016shms-ztzx10006-7).

Availability of data and materials Not applicable. 


\section{Authors' contributions}

DG and XA - literature search and review, writing, graphical design, and editing; YY and ZC - literature search and review; XX -conception and design and editing. All authors read and approved the final manuscript.

\section{Ethics approval and consent to participate}

Not applicable.

\section{Consent for publication}

Not applicable.

\section{Competing interests}

The authors declare that they have no competing interests.

\section{Publisher's Note}

Springer Nature remains neutral with regard to jurisdictional claims in published maps and institutional affiliations.

\section{Received: 8 August 2018 Accepted: 12 November 2018}

\section{Published online: 27 November 2018}

\section{References}

1. Sharma P, Allison JP. The future of immune checkpoint therapy. Science. 2015;348:56-61.

2. Buchbinder EI, Desai A. CTLA-4 and PD-1 pathways: similarities, differences, and implications of their inhibition. Am J Clin Oncol. 2016;39:98-106.

3. Menon S, Shin S, Dy G. Advances in Cancer immunotherapy in solid tumors. Cancers. 2016;8.

4. Nielsen C, Ohm-Laursen L, Barington T, Husby S, Lillevang ST. Alternative splice variants of the human PD-1 gene. Cell Immunol. 2005;235:109-16.

5. Oaks MK, Hallett KM, Penwell RT, Stauber EC, Warren SJ, Tector AJ. A native soluble form of CTLA-4. Cell Immunol. 2000;201:144-53.

6. Park J, Kwon M, Shin EC. Immune checkpoint inhibitors for cancer treatment. Arch Pharm Res. 2016;39:1577-87.

7. Ni L, Dong C. New checkpoints in cancer immunotherapy. Immunol Rev. 2017;276:52-65.

8. Fong L, Small EJ. Anti-cytotoxic T-lymphocyte antigen-4 antibody: the first in an emerging class of immunomodulatory antibodies for cancer treatment. J Clin Oncol. 2008;26:5275-83.

9. Pardoll DM. The blockade of immune checkpoints in cancer immunotherapy. Nat Rev Cancer. 2012;12:252-64.

10. Lee CS, Cragg M, Glennie M, Johnson P. Novel antibodies targeting immune regulatory checkpoints for cancer therapy. Br I Clin Pharmacol. 2013;76:233-47.

11. Saresella M, Piancone F, Marventano I, La Rosa F, Tortorella P, Caputo D, et al. A role for the TIM-3/GAL-9/BAT3 pathway in determining the clinical phenotype of multiple sclerosis. FASEB J. 2014;28:5000-9.

12. Haabeth OA, Lorvik KB, Yagita H, Bogen B, Corthay A. Interleukin-1 is required for cancer eradication mediated by tumor-specific Th1 cells. Oncoimmunology. 2016;5:e1039763.

13. Bardhan $K$, Anagnostou T, Boussiotis VA. The PD1:PD-L1/2 pathway from discovery to clinical implementation. Front Immunol. 2016;7:550.

14. O'Day SJ, Hamid O, Urba WJ. Targeting cytotoxic T-lymphocyte antigen-4 (CTLA-4): a novel strategy for the treatment of melanoma and other malignancies. Cancer. 2007;110:2614-27.

15. Schildberg FA, Klein SR, Freeman GJ, Sharpe AH. Coinhibitory pathways in the B7-CD28 ligand-receptor family. Immunity. 2016;44:955-72.

16. Hermel DJ, Ott P. Combining forces: the promise and peril of synergistic immune checkpoint blockade and targeted therapy in metastatic melanoma. Cancer Metastasis Rev. 2017;36:43-50.

17. Amancha PK, Hong JJ, Rogers K, Ansari AA, Villinger F. In vivo blockade of the programmed cell death-1 pathway using soluble recombinant PD-1-fc enhances CD4+ and CD8+ T cell responses but has limited clinical benefit. J Immunol. 2013;191:6060-70.

18. Arina A, Corrales L, Bronte V. Enhancing T cell therapy by overcoming the immunosuppressive tumor microenvironment. Semin Immunol. 2016;28:54-63.

19. Zhang X, Schwartz JC, Guo X, Bhatia S, Cao E, Lorenz M, et al. Structural and functional analysis of the costimulatory receptor programmed death-1. Immunity. 2004;20:337-47.

20. Elhag OAO, Hu X-J, Wen-Ying Z, Li X, Yuan Y-Z, Deng L-F, et al. Reconstructed adeno-associated virus with the extracellular domain of murine PD-1 induces antitumor immunity. Asian Pac J Cancer Prev. 2012;13:4031-6.
21. Sorensen SF, Demuth C, Weber B, Sorensen BS, Meldgaard P. Increase in soluble PD-1 is associated with prolonged survival in patients with advanced EGFR-mutated non-small cell lung cancer treated with erlotinib. Lung Cancer. 2016;100:77-84.

22. Cheng HY, Kang PJ, Chuang YH, Wang YH, Jan MC, Wu CF, et al. Circulating programmed death-1 as a marker for sustained high hepatitis B viral load and risk of hepatocellular carcinoma. PLoS One. 2014;9:e95870.

23. Song MY, Park SH, Nam HJ, Choi DH, Sung YC. Enhancement of vaccineinduced primary and memory CD8(+) T-cell responses by soluble PD-1. J Immunother. 2011;34:297-306.

24. Shin S-P, Seo H-H, Shin J-H, Park H-B, Lim D-P, Eom H-S, et al. Adenovirus expressing both thymidine kinase and soluble PD1 enhances antitumor immunity by strengthening CD8 T-cell response. Mol Ther. 2013;21:688-95.

25. Geng H, Zhang GM, Xiao H, Yuan Y, Li D, Zhang H, et al. HSP70 vaccine in combination with gene therapy with plasmid DNA encoding SPD-1 overcomes immune resistance and suppresses the progression of pulmonary metastatic melanoma. Int J Cancer. 2006;118:2657-64.

26. Qiu H, Liu S, Xie C, Long J, Feng Z. Regulating immunity and inhibiting tumor growth by the recombinant peptide SPD-1-CH50. Anticancer Res. 2009;29:5089-94.

27. Yuan $Y$, He $Y$, Wang $X$, Zhang $H$, Li D, Feng $Z$, et al. Investigation on the effects of soluble programmed death-1 (SPD-1) enhancing anti-tumor immune response. J Huazhong Univ Sci Technolog Med Sci. 2004;24:531-4.

28. He L, Zhang G, He Y, Zhu H, Zhang H, Feng Z. Blockade of B7-H1 with sPD1 improves immunity against murine hepatocarcinoma. Anticancer Res. 2005;25:3309-13.

29. Kuipers H, Muskens F, Willart M, Hijdra D, van Assema FB, Coyle AJ, et al. Contribution of the PD-1 ligands/PD-1 signaling pathway to dendritic cellmediated CD4+ T cell activation. Eur J Immunol. 2006;36:2472-82.

30. Xiao H, Huang B, Yuan Y, Li D, Han LF, Liu Y, et al. Soluble PD-1 facilitates 41BBL-triggered antitumor immunity against murine $\mathrm{H} 22$ hepatocarcinoma in vivo. Clin Cancer Res. 2007:13:1823-30.

31. Frigola X, Inman BA, Krco CJ, Liu X, Harrington SM, Bulur PA, et al. Soluble B7-H1: differences in production between dendritic cells and T cells. Immunol Lett. 2012;142:78-82.

32. Chen Y, Wang Q, Shi B, Xu P, Hu Z, Bai L, et al. Development of a sandwich ELISA for evaluating soluble PD-L1 (CD274) in human sera of different ages as well as supernatants of PD-L1+ cell lines. Cytokine. 2011;56:231-8.

33. He XH, Xu LH, Liu Y. Identification of a novel splice variant of human PD-L1 mRNA encoding an isoform-lacking lgv-like domain. Acta Pharmacol Sin. 2005;26:462-8.

34. Rossille D, Gressier M, Damotte D, Maucort-Boulch D, Pangault C, Semana G, et al. High level of soluble programmed cell death ligand 1 in blood impacts overall survival in aggressive diffuse large B-cell lymphoma: results from a French multicenter clinical trial. Leukemia. 2014;28:2367-75.

35. Zhou J, Mahoney KM, Giobbie-Hurder A, Zhao F, Lee S, Liao X, et al. Soluble PD-L1 as a biomarker in malignant melanoma treated with checkpoint blockade. Cancer Immunol Res. 2017;5:480-92.

36. Okuma Y, Wakui H, Utsumi H, Sagawa Y, Hosomi Y, Kuwano K, et al. Soluble programmed cell death ligand 1 as a novel biomarker for Nivolumab therapy for non-small-cell lung Cancer. Clin Lung Cancer. 2018;19:410-7 e1.

37. Zeng Z, Shi F, Zhou L, Zhang MN, Chen Y, Chang XJ, et al. Upregulation of circulating PD-L1/PD-1 is associated with poor post-cryoablation prognosis in patients with HBV-related hepatocellular carcinoma. PLoS One. 2011;6:e23621.

38. Bi XW, Wang H, Zhang WW, Wang JH, Liu WJ, Xia ZJ, et al. PD-L1 is upregulated by EBV-driven LMP1 through NF-kappaB pathway and correlates with poor prognosis in natural killer/T-cell lymphoma. J Hematol Oncol. 2016;9:109.

39. Wang L, Wang H, Chen H, Wang WD, Chen XQ, Geng QR, et al. Serum levels of soluble programmed death ligand 1 predict treatment response and progression free survival in multiple myeloma. Oncotarget. 2015;6:41228-36.

40. Huang SY, Lin HH, Lin CW, Li CC, Yao M, Tang JL, et al. Soluble PD-L1: a biomarker to predict progression of autologous transplantation in patients with multiple myeloma. Oncotarget. 2016;7:62490-502.

41. Zhang P, Ouyang S, Wang J, Huang Z, Wang J, Liao L. Levels of programmed death-1 and programmed death ligand- 1 in the peripheral blood of patients with oral squamous cell carcinoma and its clinical implications. West China J Stomatology. 2015;33:529-33.

42. Guo X, Wang J, Jin J, Chen H, Zhen Z, Jiang W, et al. High serum level of soluble programmed death ligand 1 is associated with a poor prognosis in Hodgkin lymphoma. Transl Oncol. 2018;11:779-85. 
43. Zheng Z, Bu Z, Liu X, Zhang L, Li Z, Wu A, et al. Level of circulating PD-L1 expression in patients with advanced gastric cancer and its clinical implications. Chin J Cancer Res. 2014;26:104-11.

44. Li Y, Xiao Y, Su M, Zhang R, Ding J, Hao X, et al. Role of soluble programmed death-1 (sPD-1) and SPD-ligand 1 in patients with cystic echinococcosis. Exp Ther Med. 2016;11:251-6.

45. He XH, Liu Y, Xu LH, Zeng YY. Cloning and identification of two novel splice variants of human PD-L2. Acta Biochim Biophys Sin. 2004;36:284-9.

46. Ward FJ, Dahal LN, Wijesekera SK, Abdul-Jawad SK, Kaewarpai T, Xu H, et al. The soluble isoform of CTLA-4 as a regulator of T-cell responses. Eur J Immunol. 2013;43:1274-85.

47. Magistrelli G, Jeannin P, Herbault N, Benoit De Coignac A, Gauchat JF, Bonnefoy JY, et al. A soluble form of CTLA-4 generated by alternative splicing is expressed by nonstimulated human T cells. Eur J Immunol. 1999; 29:3596-602.

48. Leung AM, Lee AF, Ozao-Choy J, Ramos RI, Hamid O, O'Day SJ, et al. Clinical benefit from Ipilimumab therapy in melanoma patients may be associated with serum CTLA4 levels. Front Oncol. 2014;4:110.

49. Laurent S, Queirolo P, Boero S, Salvi S, Piccioli P, Boccardo S, et al. The engagement of CTLA-4 on primary melanoma cell lines induces antibodydependent cellular cytotoxicity and TNF-alpha production. J Transl Med. 2013;11:108

50. Simone R, Tenca C, Fais F, Luciani M, De Rossi G, Pesce G, et al. A soluble form of CTLA-4 is present in paediatric patients with acute lymphoblastic leukaemia and correlates with CD1d+ expression. PLoS One. 2012;7:e44654.

51. Ward FJ, Dahal LN, Khanolkar RC, Shankar SP, Barker RN. Targeting the alternatively spliced soluble isoform of CTLA-4: prospects for immunotherapy? Immunotherapy. 2014;6:1073-84

52. Teft WA, Kirchhof MG, Madrenas J. A molecular perspective of CTLA-4 function. Annu Rev Immunol. 2006;24:65-97.

53. Kakoulidou M, Giscombe R, Zhao X, Lefvert AK, Wang X. Human soluble CD80 is generated by alternative splicing, and recombinant soluble CD80 binds to CD28 and CD152 influencing T-cell activation. Scand J Immunol. 2007:66:529-37.

54. Ikemizu S, Gilbert RJ, Fennelly JA, Collins AV, Harlos K, Jones EY, et al. Structure and dimerization of a soluble form of B7-1. Immunity. 2000;12:51-60.

55. Hock BD, Starling GC, Patton WN, Salm N, Bond K, McArthur LT, et al. Identification of a circulating soluble form of CD80: levels in patients with hematological malignancies. Leuk Lymphoma. 2004;45:2111-8.

56. He W, Hu ZB, Liu F, Feng XQ, Zou P. In vitro co-stimulation of anti-tumor activity by soluble B7 molecules. Acta Biochim Pol. 2006;53:807-13.

57. Sturmhoefel K, Lee K, Gray GS, Thomas J, Zollner R, O'Toole M, et al. Potent activity of soluble B7-lgG fusion proteins in therapy of established tumors and as vaccine adjuvant. Cancer Res. 1999;59:4964-72.

58. Haile ST, Horn LA, Ostrand-Rosenberg S. A soluble form of CD80 enhances antitumor immunity by neutralizing programmed death ligand-1 and simultaneously providing costimulation. Cancer Immunol Res. 2014;2:610-5.

59. Ostrand-Rosenberg S, Horn LA, Alvarez JA. Novel strategies for inhibiting PD-1 pathway-mediated immune suppression while simultaneously delivering activating signals to tumor-reactive T cells. Cancer Immunol Immunother. 2015;64:1287-93.

60. Haile ST, Dalal SP, Clements V, Tamada K, Ostrand-Rosenberg S. Soluble CD80 restores $T$ cell activation and overcomes tumor cell programmed death ligand 1-mediated immune suppression. J Immunol. 2013;191:2829-36.

61. Liu A, Hu P, Khawli LA, Epstein AL. Combination B7-fc fusion protein treatment and Treg cell depletion therapy. Clin Cancer Res. 2005;11:8492-502.

62. Todo T, Martuza RL, Dallman MJ, Rabkin SD. In situ expression of soluble B71 in the context of oncolytic herpes simplex virus induces potent antitumor immunity. Cancer Res. 2001;61:153-61.

63. Zhou ZF, Peretz Y, Chang Y, Miao DS, Li X, Prud'homme GJ. Intramuscular gene transfer of soluble B7.1/lgG(1) fusion CDNA induces potent antitumor immunity as an adjuvant for DNA vaccination. Cancer Gene Ther. 2003;10:491-9.

64. Ino $Y$, Saeki $Y$, Fukuhara $H$, Todo T. Triple combination of oncolytic herpes simplex virus-1 vectors armed with interleukin-12, interleukin-18, or soluble B71 results in enhanced antitumor efficacy. Clin Cancer Res. 2006;12:643-52.

65. Jeannin P, Magistrelli G, Aubry JP, Caron G, Gauchat JF, Renno T, et al. Soluble CD86 is a costimulatory molecule for human T lymphocytes. Immunity. 2000;13:303-12.

66. Hock BD, Patton WN, Budhia S, Mannari D, Roberts P, McKenzie JL. Human plasma contains a soluble form of CD86 which is present at elevated levels in some leukaemia patients. Leukemia. 2002;16:865-73.
67. Hock BD, McKenzie JL, Patton WN, Haring LF, Yang Y, Shen Y, et al. The clinical significance of soluble CD86 levels in patients with acute myeloid leukemia and myelodysplastic syndrome. Cancer. 2003;98:1681-8.

68. Hock BD, Drayson M, Patton WN, Taylor K, Kerr L, McKenzie JL. Circulating levels and clinical significance of soluble CD86 in myeloma patients. Br J Haematol. 2006;133:165-72.

69. Flo J, Tisminetzky S, Baralle F. Codelivery of DNA coding for the soluble form of CD86 results in the down-regulation of the immune response to DNA vaccines. Cell Immunol. 2001;209:120-31.

70. Zhang G, Hou J, Shi J, Yu G, Lu B, Zhang X. Soluble CD276 (B7-H3) is released from monocytes, dendritic cells and activated $T$ cells and is detectable in normal human serum. Immunology. 2008;123:538-46.

71. Chen W, Liu P, Wang Y, Nie W, Li Z, Xu W, et al. Characterization of a soluble $\mathrm{B} 7-\mathrm{H} 3(\mathrm{sB} 7-\mathrm{H} 3)$ spliced from the intron and analysis of $\mathrm{sB} 7-\mathrm{H} 3$ in the sera of patients with hepatocellular carcinoma. PLoS One. 2013;8:e76965.

72. Baral A, Ye HX, Jiang PC, Yao Y, Mao Y. B7-H3 and B7-H1 expression in cerebral spinal fluid and tumor tissue correlates with the malignancy grade of glioma patients. Oncol Lett. 2014;8:1195-201.

73. Masuda A, Arai K, Nishihara D, Mizuno T, Yuki H, Kambara T, et al. Clinical significance of serum soluble T cell regulatory molecules in clear cell renal cell carcinoma. Biomed Res Int. 2014;2014:396064.

74. Zhao L, Xie C, Liu D, Li T, Zhang Y, Wan C. Early detection of hepatocellular carcinoma in patients with hepatocirrhosis by soluble B7-H3. J Gastrointest Surg. 2017;21:807-12.

75. Chen L, Zhang G, Sheng S, Zhou Q, Pan Y, Guan S. Upregulation of soluble B7-H3 in NSCLC-derived malignant pleural effusion: A potential diagnostic biomarker correlated with NSCLC staging. Clin Chim Acta. 2016:457:81-5.

76. Sun J, Mao Y, Zhang YQ, Guo YD, Mu CY, Fu FQ, et al. Clinical significance of the induction of macrophage differentiation by the costimulatory molecule B7-H3 in human non-small cell lung cancer. Oncol Lett. 2013;6:1253-60.

77. Xie C, Liu D, Chen Q, Yang C, Wang B, Wu H. Soluble B7-H3 promotes the invasion and metastasis of pancreatic carcinoma cells through the TLR4/NFkappaB pathway. Sci Rep. 2016;6:27528.

78. Thum E, Shao Z, Schwarz H. CD137, implications in immunity and potential for therapy. Front Biosci. 2009;14:4173-88.

79. Michel J, Schwarz H. Expression of soluble CD137 correlates with activationinduced cell death of lymphocytes. Cytokine. 2000;12:742-6.

80. Dimberg J, Hugander A, Wagsater D. Expression of CD137 and CD137 ligand in colorectal cancer patients. Oncol Rep. 2006;15:1197-200.

81. Furtner M, Straub RH, Kruger S, Schwarz H. Levels of soluble CD137 are enhanced in sera of leukemia and lymphoma patients and are strongly associated with chronic lymphocytic leukemia. Leukemia. 2005;19:883-5.

82. Labiano S, Palazon A, Bolanos E, Azpilikueta A, Sanchez-Paulete AR, MoralesKastresana A, et al. Hypoxia-induced soluble CD137 in malignant cells blocks CD137L-costimulation as an immune escape mechanism. Oncoimmunology. 2016;5:e1062967.

83. Bellarosa D, Bressan A, Bigioni M, Parlani M, Maggi CA, Binaschi M. SAHA/ Vorinostat induces the expression of the CD137 receptor/ligand system and enhances apoptosis mediated by soluble CD137 receptor in a human breast cancer cell line. Int J Oncol. 2012:41:1486-94.

84. Krishna M, Nadler SG. Immunogenicity to biotherapeutics - the role of antidrug immune complexes. Front Immunol. 2016;7:21.

85. Wan B, Nie H, Liu A, Feng G, He D, Xu R, et al. Aberrant regulation of synovial T cell activation by soluble costimulatory molecules in rheumatoid arthritis. J Immunol. 2006;177:8844-50.

86. Li S, Liao W, Chen M, Shan S, Song Y, Zhang S, et al. Expression of programmed death-1 (PD-1) on CD4+ and CD8+ T cells in rheumatoid arthritis. Inflammation. 2014;37:116-21.

87. Birtas Atesoglu E, Tarkun P, Demirsoy ET, Geduk A, Mehtap O, Batman A, et al. Soluble programmed death 1 (PD-1) is decreased in patients with immune thrombocytopenia (ITP): potential involvement of PD-1 pathway in ITP Immunopathogenesis. Clin Appl Thromb Hemost. 2016;22:248-51.

88. Wang D, Zhou D, Du Q, Liang Q, Wang Q, Fang L, et al. Aberrant production of soluble inducible T-cell co-stimulator (sICOS) and soluble programmed cell death protein 1 (SPD-1) in patients with chronic hepatitis C. Mol Med Rep. 2013;7:1197-202.

89. Wu H, Miao M, Zhang G, Hu Y, Ming Z, Zhang X. Soluble PD-1 is associated with aberrant regulation of $T$ cells activation in aplastic anemia. Immunol Investig. 2009;38:408-21. 
90. Zhao Y, Jia Y, Li C, Shao R, Fang Y. Predictive Value of Soluble Programmed Death-1 for Severe Sepsis and Septic Shock During the First Week in an Intensive Care Unit. Shock. 2018. https://doi.org/10.1097/SHK. 0000000000001171.

91. Monaghan SF, Chung CS, Chen Y, Lomas-Neira J, Fairbrother WG, Heffernan DS, et al. Soluble programmed cell death receptor-1 (SPD-1): a potential biomarker with anti-inflammatory properties in human and experimental acute respiratory distress syndrome (ARDS). J Transl Med. 2016;14:312.

92. Nasiri Kalmarzi R, Fattahi N, Kaviani Z, Ataee P, Mansouri M, Moradi G, et al. Inverse correlation of soluble programmed cell death-1 ligand-1 (sPD-L1) with eosinophil count and clinical severity in allergic rhinitis patients. Allergol Int. 2017:66:326-31.

93. Chen X, Guo H, Li S, Liu C, Ding S, Huang Y, et al. Soluble programmed death-1 ligand 1(SPD-L1) is significantly reduced in the serum of type 1 diabetes patients. Acta Diabetol. 2018;55:515-7.

94. Shi B, Du X, Wang Q, Chen Y, Zhang X. Increased PD-1 on CD4(+ )CD28(-) T cell and soluble PD-1 ligand-1 in patients with T2DM: association with atherosclerotic macrovascular diseases. Metab Clin Exp. 2013;62:778-85

95. Fukasawa T, Yoshizaki A, Ebata S, Nakamura K, Saigusa R, Miura S, et al. Contribution of soluble forms of programmed death 1 and programmed death ligand 2 to disease severity and progression in systemic sclerosis. Arthritis Rheumatol. 2017:69:1879-90.

96. Cao J, Zou L, Luo P, Chen P, Zhang L. Increased production of circulating soluble co-stimulatory molecules CTLA-4, CD28 and CD80 in patients with rheumatoid arthritis. Int Immunopharmacol. 2012;14:585-92.

97. Cao J, Zhang L, Huang S, Chen P, Zou L, Chen H, et al. Aberrant production of soluble co-stimulatory molecules CTLA-4 and CD28 in patients with chronic hepatitis B. Microb Pathog. 2011:51:262-7.

98. Gerold KD, Zheng P, Rainbow DB, Zernecke A, Wicker LS, Kissler S. The soluble CTLA-4 splice variant protects from type 1 diabetes and potentiates regulatory T-cell function. Diabetes. 2011;60:1955-63.

99. Toussirot E, Saas P, Deschamps M, Pouthier F, Perrot L, Perruche S, et al. Increased production of soluble CTLA-4 in patients with spondylarthropathies correlates with disease activity. Arthritis Res Ther. 2009:11:R101.

100. Ip WK, Wong CK, Leung TF, Lam CW. Plasma concentrations of soluble CTLA-4, CD28, CD80 and CD86 costimulatory molecules reflect disease severity of acute asthma in children. Pediatr Pulmonol. 2006; 41:674-82.

101. Hock BD, O'Donnell JL, Taylor K, Steinkasserer A, McKenzie JL, Rothwell $A G$, et al. Levels of the soluble forms of CD80, CD86, and CD83 are elevated in the synovial fluid of rheumatoid arthritis patients. Tissue Antigens. 2006;67:57-60.

102. Wong CK, Lit LC, Tam LS, Li EK, Lam CW. Aberrant production of soluble costimulatory molecules CTLA-4, CD28, CD80 and CD86 in patients with systemic lupus erythematosus. Rheumatology. 2005:44:989-94.

103. Shi HZ, Xie ZF, Deng JM, Chen YQ, Xiao CQ. Soluble CD86 protein in serum samples of patients with asthma. Thorax. 2004;59:870-5.

104. Zhang G, Wang J, Kelly J, Gu G, Hou J, Zhou Y, et al. B7-H3 augments the inflammatory response and is associated with human sepsis. J Immunol. 2010;185:3677-84.

105. Wei $X$, Zhang G, Yuan H, Ding $X$, Li S, Zhang $X$, et al. Detection and quantitation of soluble B7-H3 in expressed prostatic secretions: a novel marker in patients with chronic prostatitis. J Urol. 2011;185:532-7.

106. Jiang J, Jiang J, Liu C, Zhang G, Gao L, Chen Y, et al. Enhancement of membrane $\mathrm{B} 7-\mathrm{H} 3$ costimulatory molecule but reduction of its soluble form in multiple sclerosis. J Clin Immunol. 2013;33:118-26.

107. Luan Y, Ju J, Luo L, Zhang Z, Wang J, Zhu DM, et al. Potential role of soluble B7-H3 in liver immunopathogenesis during chronic HBV infection. J Viral Hepat. 2012;19:23-31.

108. Sun J, Lai H, Shen D, Wu P, Yang J, Sun Z, et al. Reduced sB7-H3 expression in the peripheral blood of systemic lupus erythematosus patients. J Immunol Res. 2017;2017:5728512.

109. Shao Z, Schaffler A, Hamer O, Dickopf J, Goetz A, Landfried K, et al. Admission levels of soluble CD137 are increased in patients with acute pancreatitis and are associated with subsequent complications. Exp Mol Pathol. 2012:92:1-6.

110. Yan J, Wang C, Chen R, Yang H. Clinical implications of elevated serum soluble CD137 levels in patients with acute coronary syndrome. Clinics. 2013;68:193-8.
111. Sharief MK. Heightened intrathecal release of soluble CD137 in patients with multiple sclerosis. Eur J Neurol. 2002;9:49-54.

112. Jung HW, Choi SW, Choi Jl, Kwon BS. Serum concentrations of soluble 4$1 \mathrm{BB}$ and $4-1 \mathrm{BB}$ ligand correlated with the disease severity in rheumatoid arthritis. Exp Mol Med. 2004;36:13-22.

113. He Y, Ao DH, Li XQ, Zhong SS, A R, Wang YY, et al. Increased Soluble CD137 Levels and CD4+ T-Cell-Associated Expression of CD137 in Acute Atherothrombotic Stroke. Clin Transl Sci. 2018;11:428-34.

\section{Ready to submit your research? Choose BMC and benefit from:}

- fast, convenient online submission

- thorough peer review by experienced researchers in your field

- rapid publication on acceptance

- support for research data, including large and complex data types

- gold Open Access which fosters wider collaboration and increased citations

- maximum visibility for your research: over $100 \mathrm{M}$ website views per year

At BMC, research is always in progress.

Learn more biomedcentral.com/submissions 